\title{
Nurses' Role in Post-Operative Immediately Myocardial Revascularization in Intensive Care Unit

Katianere Alessandra Silva ${ }^{1}$, Soraya Maria de Medeiros ${ }^{2}$, Tayssa Suelen Cordeiro Paulino ${ }^{3}$, Fabio Claudiney da Costa Pereira ${ }^{4}$, Karolina de Moura Manso da Rocha ${ }^{5}$, Isabel Cristina Amaral de Sousa Rosso Nelson ${ }^{6}$, Ilara Maria Ferreira Alves ${ }^{7}$

\section{Abstract}

Introduction: Coronary Artery Bypass Surgery (CABG) is one of the main options for treating coronary artery disease.

Objective: To describe the nursing care in the immediate postoperative period in $C A B G$ surgery in the ICU.

Method: This is an integrative review, which seeks to gather and synthesize the information gathered for analysis of the data was performed a reading in full the findings and discussed later, preserving the ethical and legal principles of each study.

Results: Nursing care should be developed with quality and competence by nurses and all his team, comprising all the POI period in ICU within 24 hours, it is of utmost importance to prevent possible complications.

Conclusion: The nurse has the key role in the admission of that patient in the ICU, assessing and caring in comprising the SVR postoperative ICU.

\section{Keywords}

Myocardial revascularization; Heart surgery; Nursing care; Nursing care planning.

1 Academic UNIFACEX of the nursing course of the 10th period.

2 Nurse. PhD in Education from USP. Professor of the graduate program in nursing of UFRN.

3 Nurse. PhD student of the graduate program in nursing of UFRN. undergraduate course teaching in UNIFACEX of Nursing.

4 Nurse. Master's graduate program in nursing of UFRN. undergraduate course teaching in UNIFACEX of Nursing.

5 Nurse. Master in Nursing graduate program in nursing of UFRN. Undergraduate course teaching in UNIFACEX of Nursing.

6 Nurse. PhD in Education at postgraduate program in Education UFRN. undergraduate course teaching in UNIFACEX of Nursing.

7 Academic UNIFACEX of the nursing course of the 9th period.

\section{Contact information:}

Tayssa Suelen Cordeiro Paulino.

Address: End. R. Orlando Silva, 2897. Capim Macio, Natal. RN, 59080-020. Tel: (84) 3235-1415 (ramal=261)

झ tata_suelen@hotmail.com

\section{Introduction}

Cardiovascular diseases are the leading causes of death in Brazil, cardiac surgery of its forms of treatment, the therapeutic approach 
to circulatory diseases, they can be clinical or invasive procedures surgical. It is noteworthy that heart surgery for coronary artery bypass grafting $(C A B G)$, it is only indicated treatment when the chances of survival is much higher with surgery than with clínico. [1]

In this sense, coronary artery bypass surgery is performed a bridge (bypass), better known as bypass surgery, it is a large complex surgical procedure in the arteries coronárias. [2]

From the 50, the implementation of intensive care units has added positively in the support and maintenance of life in this sense the ICU, it is intended to care for patients of risks or serious, requiring medical care and specialized nursing and continued in the early hours, using the use of equipment with full cardiac monitoring, specific and high tecnologia. [3]

ICUs in general, they are organized in different specialties, as well as the cardiac ICU, where professionals are able to intervene in a precise and skilled to provide assistance to cardiac patients, so there is only indication of heart surgery treatment when the probability of life of this patient is higher than the clínico. [3]

The nursing care in the $\mathrm{POI}$ in the ICU, has as main objective to observe in the early hours, strict control through continuous monitoring and maintain hemodynamic stability in the post-anesthetic recovery, and ensure a free recovery without any changes and complications. [3]

Thus, this study will address the importance and the need of nursing care, as many are needed for patients in the immediate postoperative period of cardiac surgery, where such care is often complex, due to hemodynamic instability of the patient, require nurses and his team, a performance needs, based on nursing care, which seeks to decisionmaking focused on identifying the needs of the patient.

In this perspective, this study aims to describe the role of nurses in nursing care in the immediate postoperative period of myocardial revascularization in the intensive care unit.

\section{Method}

Study of the integrative review type for the preparation is traveled, the following steps: setting the goal of integrative review; demarcation criteria for inclusion and exclusion of articles; definition of the information to be extracted from selected articles; analyzing the results; discussion and presentation of the results and the final stage, the presentation of the review.

To guide this research was formulated the following question: what is the role of nurses in nursing care in the immediate postoperative period of myocardial revascularization in the intensive care unit?

Data collection was performed by means of databases SCIELO (Scientific Electronic Library Online), CINAHL (Cumulative Index to Nursing and Allied Health Literature), LILACS (Latin American Literature in Health and the Caribbean Sciences), MEDLINE (Medical Literature Analysis and Retrieval System Online) and COCHRANE, using the Health Sciences Descriptors: revascularization; nursing care; ICU.

For that we used a structured questionnaire with information database, the location of the study authors, title of the article, objective, study design, subject, main results and conclusion.

We used the following inclusion criteria: articles available in English, Spanish and Portuguese, published between 2005 and 2015 that addressed related issues to the nursing consultation in the immediate postoperative period of myocardial revascularization and full texts of which were freely accessible online. Thus, they excluded up publications that had duplications and were available in summary form.

For review of articles held full reading with their syntheses. They were later classified by the year of publication; site development of research and addressed themes. The results were presented in 
tables with frequencies and percentages and supported discussion with literature.

The data used in this study were properly referenced, respecting and identifying the authors and other sources of research, observing ethical rigor and intellectual property of scientific texts that were surveyed, with regard to the use of content and citation of parts of the works consulted.

\section{Results}

Met a total of 20 articles, however, were used only 08 articles, and 03 references that shared with the objective of the research in question. The articles were arranged as follows in databases: LILACS (1 articles) SCIELO (5 articles) and MEDLINE (1 articles).

\section{Table 1}

For the year of publication predominated in the year 2012 (5). However, there was a equiparidade between the years 2010 (1) 2011 (1) 2014 (1) and being for 2006 (2). Table 2

Regarding the location of the publications, the Northeast region has low levels in relation to the South and Southeast. It is important to note that during the study were not found studies in the North and Midwest regions. Table 3

\section{Discussion}

Worldwide, cardiovascular chronic diseases are responsible for leading causes of death. Being the most important for public health, it is cardiovascular, and subsequently cancer and diabetes mellitus. [4]

Table 1. Distribution of studies in accordance with the year of publication, database, title, type of approach and main outcomes 2016.

\begin{tabular}{|c|c|c|}
\hline Source & $\begin{array}{c}\text { Year of } \\
\text { publication }\end{array}$ & Title \\
\hline \multirow{6}{*}{ Sielo } & 2010 & Diagnósticos de enfermagem em pacientes no período pós-operatório de cirurgias cardíacas \\
\hline & 2009 & Cuidados de enfermagem realizados ao pacientes cirúrgicos no período pré-operatório \\
\hline & 2006 & Diagnósticos de enfermagem em pacientes submetidos á cirurgia cardíaca \\
\hline & 2014 & Impact of Intensive Physiotherapy on Cognitive Function after Coronary Artery Bypass Graft Surgery \\
\hline & 2012 & Circulação extracorpórea e complicações no período pós-operatório imediato de cirurgias cardíacas \\
\hline & 2012 & O cuidado de enfermagem no pós-operatório de cirurgia cardíaca: um estudo de caso \\
\hline Lilacs & 2012 & Mapeamento dos cuidados de enfermagem para pacientes em pós-operatório de cirurgia cardíaca \\
\hline Medline & 2012 & Cuidados de enfermagem no pós-operatório imediato de revascularização do miocárdio \\
\hline
\end{tabular}

Table 2. Disposition of articles as year of publication, 2016.

\begin{tabular}{|c|c|c|}
\hline Year of publication & Number of publications & $\%$ \\
\hline 2006 & 2 & 20 \\
\hline 2009 & 1 & 10 \\
\hline 2010 & 1 & 10 \\
2012 & 5 & 50 \\
\hline 2014 & 1 & 10 \\
\hline
\end{tabular}

Table 3. Distribution of articles according to the place where the research was conducted, by regions, 2016.

\begin{tabular}{|c|c|c|}
\hline Region & Number of publications & $\%$ \\
\hline South & 4 & 40 \\
\hline Southeast & 4 & 40 \\
\hline Northeast & 2 & 20 \\
\hline
\end{tabular}


There are three types of cardiac surgery: the brokers, for the closure of the ductus arteriosus, a defect of the atrial and ventricular septum; the reconstructive, for myocardial revascularization, plasty of the aortic valve, mitral or tricuspid; and substitutive, which are for valvular and transplants exchanges, depending on the patient's impairment. Among them, the most common are the reconstructive coronary artery bypass grafting (CABG). [5]

In Brazil, cardiovascular diseases are responsible for the second contingent of hospitalares 6 admissions. In cardiovascular complications stand the coronary artery disease, cerebrovascular and systemic hypertension (SH).

Heart disease is one of the most common heart disease, and it is usually caused by the buildup of plaque and fatty deposits that accumulate on the walls of the arteries, atherosclerosis, this buildup causes hardening and narrowing of the coronary arteries. (Hospital Balbino, surgery cardíaca- Manual postoperative). [7]

The bypass coronary artery (abbreviation: CABGcoronary artery bypass graft), used for the grafts come from the patient's own body, they are: (saphenous vein, internal mammary artery, radial artery, etc.), thus function as a bridge, where the obstruction is taken blood to the coronary artery. The most used saphenous vein is internal (magna) ascends on the medial side of the leg side by side with the nerve frênico. [2]

The traditional procedure of CABG is performed by sternotomy, but in some cases the surgery, there is need for full cardiac arrest, when establishing the extracorporeal circulation (ECC), and all the blood movement and oxygenation. [8]

The main objective of surgical treatment (MRI) is the correction of myocardial ischemia, to relieve angina, prevent heart attacks, improve ventricular function, improving and prolonging the quality life. [8]

Having seen that the precursor of sudden death and myocardial infarction is the presence of myocar- dial ischemia, more than angina. Therefore, cardiac surgery is very important and is only indicated in the evidence of myocardial existence at rest or induced efforts. [8]

It should be emphasized that in some cases surgery after the perioperative period the patient is transferred directly to the post-anesthetic recovery room (CRO). In the case of coronary artery bypass grafting $(C A B G)$, the patient is directly transferred to the ICU corresponding to 24 hours immediately, it shows that the postoperative period is considered a critical period for the patient post surgery, especially in cardiac surgery due High will complexidade. [7]

During this period the assistance of nursing through the routine knowledge of the ICU, is linked to interventions to prevent or treat any complication, providing an alternative to prolong the life of this patient, and in this perspective the return chances Ace everyday activities. [2]

The main complications that can occur in SVR postoperative ICU are: hypertension, cardiac output changes, pulmonary hypertension, the frequency changes and heart rhythms, pneumothorax, atelectasis, pneumonia, kidney failure, bleeding disorders, blood volume balance and electrolyte, neurological problems, cardiac tamponade, and changes resulting from dor. [2]

After the end of CABG surgery, are performed every effort and agility to facilitate the patient leaves the operating room to the ICU with minimal risk, thus will nursing care to patients in the first 24 hours (POI) after CABG, focuses on interventions in care directly with the patient, to prevent or treat complications, and the nurse's knowledge about these risks, as well as through knowledge and basic needs of the patient in surgical step, provide a better direction in Nursing diagnoses and systematization of assistence. [9]

With this, the nurse professional, he will act through care protocols, obtaining better planning of nursing care, and together will systematization 
of nursing care, which will promote the implementation of effective interventions for patients in order to promote and achieve better prognostic. [9]

It should be emphasized that the protocol means a series of procedures, which establishes allowable actions and serves as a tool where nurses can implement them for immediate interventions involving unifying risks of life with the nursing staff in their daily practice, enabling professional practice safer and effective. [2]

It is important to remember the current concepts of leadership, where the leader is the one who influences, directs the course guides the way, the views and the course of action, increasing productivity and maximizing work efficiency in equipe. [10]

In this context, given the complexity, the patient RVM POI in the ICU requires nursing in their work process to develop the following actions: bed pre- paration in the ICU, hemodynamic changes in the first 24 hours, in support of mechanical ventilation/ oxygenation, heart rate, body temperature, in neurological status, in the strict control of SSVV, the control/electrolyte balance and other special care that the patient needs.

It is up to the professional nurse, secure and test the materials, devices and equipment, ensuring safety for the patient more effective. [2]

Corroborating these assumptions, developing the table below specifying the role of nurses in the care process in POI. Table 4

The nurse is one of the professionals who make up the team responsible for the care of these surgical patients after surgery, therefore, can identify and assess feelings and perceptions of them before the disease and health. From this he develops a plan of care and guidance directly related to the needs of

Table 4. Distribution of possible diagnoses, interventions and expected results in the care of patients in POI. 2016.

\begin{tabular}{|c|c|}
\hline Nursing diagnoses & Average \\
\hline \multirow[t]{2}{*}{ Risk of infection } & $\begin{array}{l}\text { Perform hand hygiene before and after the procedure and where necessary to } \\
\text { the use of Personal Protective Equipment (PPE) }\end{array}$ \\
\hline & Perform dressing change whenever needed using aseptic technique. \\
\hline $\begin{array}{l}\text { Pain related to surgery } \\
\text { evidenced by report }\end{array}$ & Drug Administration for pain relief; \\
\hline $\begin{array}{l}\text { Volume excessive } \\
\text { liquid }\end{array}$ & $\begin{array}{l}\text { Administer prescribed drugs (eg diuretics, cardiotonics, corticosteroids, } \\
\text { plasma or albumin as volume expanders). Limit the intake of sodium and fluids } \\
\text { as prescribed. Calculate the balance of fluids in } 24 \text { hours (positive or negative). }\end{array}$ \\
\hline Bleeding risk & $\begin{array}{l}\text { Maintain vascular access patents to administer liquids or replenish blood, as } \\
\text { prescribed. Collaborate in the treatment of coexisting disorders that caused } \\
\text { or contributed to the bleeding. Carefully monitor the occurrence of obvious } \\
\text { bleeding. Observe if there is diffuse bleeding through the tubes, drains, } \\
\text { wounds and orifices with no detectable clotting. Administer hemostatic agent } \\
\text { that promote clotting and can stop bleeding by raising the levels of clotting } \\
\text { factors; or drugs to prevent bleeding. }\end{array}$ \\
\hline $\begin{array}{l}\text { Decreased cardiac } \\
\text { output }\end{array}$ & $\begin{array}{l}\text { Keep the patient on bed rest with congestive heart failure, it should be } \\
\text { preferred will semi- fowler position). In shock presence, members can be } \\
\text { raised to } 20 \text { to 30, it reduces oxygen consumption and reduces the risk of } \\
\text { decompensation. Conduct periodic hemodynamic measurements, as will } \\
\text { prescription (eg blood pressure, PVC, pulmonary pressures, and left atrial and } \\
\text { cardiac output). Administer blood or fluid replacement, antibiotics, diuretics, } \\
\text { inotropic agents, antiarrítimicos, corticosteroids, vasopressors or vasodilators } \\
\text { and, as prescribed. }\end{array}$ \\
\hline
\end{tabular}

Perform hand hygiene before and after the procedure and where necessary to the use of Personal Protective Equipment (PPE)

Perform dressing change whenever needed using aseptic technique.

Pain related to surgery Drug Administration for pain relief

Volume excessive plasma or albumin as volume expanders). Limit the intake of sodium and fluids as prescribed. Calculate the balance of fluids in 24 hours (positive or negative)

\section{Median}

Improvement of the general framework.

Relief or mitigation of pain.

Promote mobilization elimination of excess fluids.

Prevent bleeding or to correct potential causes of excessive blood loss.

Mitigate or eliminate the etiologic factors and increase cardiac output. 


\begin{tabular}{|c|c|c|}
\hline Nursing diagnoses & Average & Median \\
\hline $\begin{array}{l}\text { Ineffective cerebral } \\
\text { perfusion Risk }\end{array}$ & $\begin{array}{l}\text { Restore or maintain fluid balance, to increase cardiac output and prevent } \\
\text { reduction of cerebral perfusion associated with hypovolemia. Control cardiac } \\
\text { arrhythmias by means of drugs or placement of a pacemaker. Limit fluid } \\
\text { intake and administering diuretics as prescribed to avoid reduction of cerebral } \\
\text { perfusion associated with hypertension and cerebral edema. Administering } \\
\text { vasoactive drugs as prescribed to increase cardiac output and or adequate } \\
\text { blood pressure and maintain cerebral perfusion. Review the modifiable risk } \\
\text { factors, including hypertension, smoking, diet, physical activity, excessive intake } \\
\text { of alcohol and illicit drug use, as appropriate. }\end{array}$ & $\begin{array}{l}\text { Maximize tissue } \\
\text { perfusion, } \\
\text { promote wellness. }\end{array}$ \\
\hline $\begin{array}{l}\text { Ineffective renal } \\
\text { perfusion Risk }\end{array}$ & $\begin{array}{l}\text { Collaborate in the treatment of coexisting disorders (eg, angioplasty with } \\
\text { stenting, bypass surgery, fluids and electrolytes, nutrients, antibiotics, } \\
\text { thrombolytics, oxygen) to improve tissue perfusion and organ function. } \\
\text { Administer drugs (eg vasoactive agents, including antihypertensives, insulin) } \\
\text { as prescribed to treat the coexisting disorder and improve blood flow and } \\
\text { function of the kidneys. Talk about personal risk factors (eg, family history, } \\
\text { obesity, age, smoking, hypertension, diabetes, coagulation disorders) and the } \\
\text { potential consequences of atherosclerosis, including systemic vascular disease } \\
\text { and peripheral. }\end{array}$ & $\begin{array}{l}\text { Reduce or } \\
\text { eliminate the } \\
\text { personal risk } \\
\text { factors and } \\
\text { promote wellness }\end{array}$ \\
\hline
\end{tabular}

Source: Adaptation of NANDA [11].

each patient to include family care and post-discharge rehabilitation. In this context, it is also for nurses to clarify the patient and family about the care directly with its limitations, as the wound, which include restriction of movement, avoid efforts with arms, in order to prevent risks to the surgical procedure they underwent. [12]

Nurses are the best people to start the process of care in the immediate postoperative period of cardiac surgery $(C A B G)$, and maintain education programs to the patient, because they know and follow throughout their hospitalization, can develop and fulfill these programs ensuring specific information about what patients can expect to after discharge. [13]

\section{Conclusion}

The postoperative period of cardiac surgery is a unique moment for the patient and his family. A moment full of fears, uncertainties and insecurities, where we seek new life after the reconstruction of the heart- organ of the senses and feelings.

In this period of the immediate postoperative period of cardiac surgery ICU, see the patient and understanding their needs is not a simple task, but the advanced technology and machinery will ensure and evaluate infusions, beats, debts, ventilations, and the whole operation the body, allowing the nurse to its basic premise: the care to humans.

The need for planning is a factor that should be highlighted in the Intensive Care Unit of RVM immediate postoperative Plan assistance is to promote communication among all the members that make up will ICU, is knowing direct care and create records that allow patient care. It is an inherent activity of the nurse, team leader, in order to address the needs of patients defining diagnoses, prescribing care and evaluating the results, ensuring a safe recovery and no complications that may intervene this recovery.

In this study performed, it was possible to reflect on the needs of the patient in the postoperative period of cardiac surgery and how these needs are identified by nurses and by understanding the organization of care outside the immediate postoperative period, which measures to adopt, which conducts, routines and guidelines, thus ensuring a more humanized nursing care, facilitating planning and increasing the quality of care for this patient. 


\section{References}

1. Pivoto FL et al. Diagnósticos de enfermagem em pacientes no período pós-operatório de cirurgias cardíacas. Acta Paul Enferm [online] 2010 [cited 2016 Jan 10] ;23(5):665-70. Disponível: http://www.scielo.br/pdf/ape/v23n5/13.pdf

2. Maia MA; Sade PMC. Cuidados de enfermagem no pósoperatório imediato de revascularização do miocárdio. Rev Elet evangélica do Paraná [online] 2012 [cited 2016 Mar 21]; 2(3):1831 . Avaliable from: http://www.fepar.edu.br/revistaeletronica/ index.php/revfepar/article/view/53/65

3. Christóforo BEB, Carvalho DS. Cuidados de enfermagem realizados ao pacientes cirúrgicos no período pré-operatório. Rev Esc Enf erm USP [online] 2009 [cited 2016 Jan 10]; 43(1): 14-22. Avaliable from: http://www.scielo.br/pdf/reeusp/v43n1/02.pdf

4. Rocha LA, Maia TF, Silva LF. Diagnósticos de enfermagem em pacientes submetidos á cirurgia cardíaca. Rev. bras. enferm. [online] 2006 [cited 2016 Mar 21]; 59(3):321-6. Avaliable from: http://www.scielo.br/pdf/reben/v59n3/a13v59n3.pdf

5. Lira ALBC et al. Mapeamento dos cuidados de enfermagem para pacientes em pós-operatório de cirurgia cardíaca. Rev RENE [online] 2012 [cited 2016 Abr 08]; 13(5): 1171-81. Avaliable from: http://www.revistarene.ufc.br/revista/index.php/revista/ article/view/241/pdf.

6. Cavalcante ES, Magario R, Conforti CA, Cipriano Júnior G, Arena R, Carvalho ACC. et al. Impact of Intensive Physiotherapy on Cognitive Function after Coronary Artery Bypass Graft Surgery. Arq. Bras. Cardiol. [Internet]. 2014 Nov [cited 2015 Dec 17]; 103(5): 391-397. Available from: http:// www.scielo.br/scielo.php?script=sci arttext $\&$ pid $=$ S0066782X2014002300005\&lng=en.

7. Torrati FG, Dantas RAP. Circulação extracorpórea e complicações no período pós-operatório imediato de cirurgias cardíacas. Acta Paul Enferm [online] 2012 [cited 2016 Mar 21];25(3):340-345. Avaliable from: www.scielo.br/pdf/ape/v25n3/v25n3a04.pdf

8. Barretto ACP, Moraes RS. Cardiologia atualização e reciclagem (org.), Sociedade de Cardiologia do estado de São Paulo. Rio de Janeiro; Atheneu, 1994.

9. Duarte SCM et al. O cuidado de enfermagem no pós-operatório de cirurgia cardíaca: um estudo de caso. Esc Anna Nery [impr.] 2012 [cited 2016 Jan 10]; 16 (4):657 - 665. Avaliable from: http://www.scielo.br/pdf/ean/v16n4/03.pdf

10. Chiavenato I. Princípios de administração: o essencial em teoria geral da administração. Rio de Janeiro: Elsevier; 2006.

11. NANDA. Diagnósticos de enfermagem da NANDA: definições e classificação (2007-2008). Porto Alegre: Artmed; 2007.
12. Coppetti LC, Stumm EMF, Benetti ERR. Considerações de pacientes no perioperatório de cirurgia cardíaca referentes ás orientações recebidas do enfermeiro. Rev. Min. Enferm. [on line] 2015 jan-mar [cited 2016 Jul 10]; 19(1): 113-119. Avaliable from: http://www.reme.org.br/exportar-pdf/990/v19n1a10.pdf

13. Carvalho LDP, Mamede MV, Araujo MRO. Conhecimento de pacientes sobre o processo de auto-cuidado em pós-operatório de cirurgia cardíaca. Cad. Pesq. [on line] 2011 dez [cited 2016 Jul 10]; 18(n.esp):18-25. Avaliable from: http://www. periodicoseletronicos.ufma.br/index.php/cadernosdepesquisa/ article/view/734/2572

\section{Publish in International Archives of Medicine}

International Archives of Medicine is an open access journal publishing articles encompassing all aspects of medical science and clinical practice. IAM is considered a megajournal with independent sections on all areas of medicine. IAM is a really international journal with authors and board members from all around the world. The journal is widely indexed and classified Q1 in category Medicine. 